\title{
Eocene Brachiopods
}

\section{From Eua, Tonga}

GEOLOGICAL SURVEY PROFESSIONAL PAPER 640-F

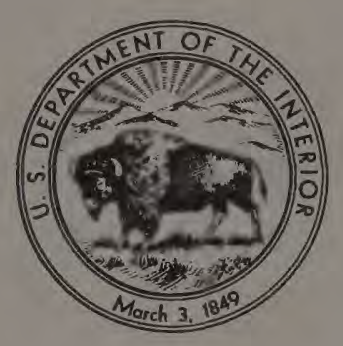




\section{Eocene Brachiopods}

\section{From Eua, Tonga}

By G. ARTHUR COOPER

With a summary statement on TELEOST OTOLITHS

By JOHN E. FITCH

\section{LATE EOCENE FOSSILS FROM EUA, TONGA}

GEOLOGICAL SURVEY PROFESSIONAL PAPER 640-F

Brachiopods representing six genera are recognized from tuffaceous limestone

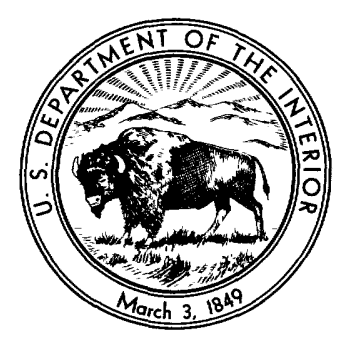




\title{
UNITED STATES DEPARTMENT OF THE INTERIOR \\ ROGERS G. B. MORTON, Secretary
}

\section{GEOLOGICAL SURVEY}

\author{
W. A. Radlinski, Acting Director
}

Library of Congress catalog-card No. 72-176117

For sale by the Superintendent of Documents, U.S. Government Printing Office Washington, D.C. 20402 - Price 45 cents (paper cover)

Stock Number 2401-2022 


\section{LATE EOCENE FOSSILS FROM EUA, TONGA-FOREWORD}

One of the most widespread units of the Cenozoic section in the islands of the open Pacific is a series of limestones assigned to the upper Eocene (Tertiary $b$ ). Such limestones, containing diagnostic larger Foraminifera, have been reported in many parts of an area spreading 4,000 miles across the tropical Pacific (fig. 1), from Palau and the Mariana Islands on the northwest through the Marshall Islands (Eniwetok) to Fiji and Tonga on the southeast (Whipple, in Hoffmeister, 1932, p. 79-86; Asano, 1939; Cole, 1950, 1957a, 1957b, 1960). In almost all the islands the limestones are dense and crystalline. Foraminifera and algae are abundant locally, but in most places fossils cannot be extracted and must therefore be studied in random thin sections. On the little island of Eua, Tonga, a locality was recently found where the Eocene limestone is tuffaceous, considerably weathered, and richly fossiliferous. Abundant fossils that represent a dozen organic groups were found. Such abundance and diversity signaled the find as a remarkable one that would add greatly to our knowledge of life in the western Pacific during the Eocene.

The island of Eua measures only 12 by 5 miles but it rises 1,000 feet above sea level. It occupies an interesting position tectonically, as its steep eastern side faces the Tonga Trench. In addition, Eua is the oldest island in the Tonga group that has a plutonic core (Guest, 1959) and a series of associated volcanic rocks, which are partly blanketed by thick limestones of late Eocene age. Younger volcanic rocks and sediments of late Tertiary age are also present (Hoffmeister, 1932).

This series of reports is concerned with one facies of the upper Eocene limestone. After the limestone series was deposited, Eua was uplifted periodically and a sequence of six terraces was cut in the limestones on the windward (eastern) side. Hoffmeister was the first to recognize the Eocene age of the main limestone of the terraces, three of which have veneers of Pliocene reef corals. He made a planetable map of the terraced eastern ridge and recorded the average altitudes of the terraces as $100,200,340,400,550$, and 760 feet. The east-facing "rocky backbone" of Eua thus looks in profile like a giant staircase facing the Tonga Trench. The Eocene limestone may once have covered all of Eua but is now largely limited to the eastern ridge (Hoffmeister, 1932; the Eocene Foraminifera were described by Whipple in this same report, p. 79-\&6).

The fossils described in this series of reports were obtained from an outcrop on he 400-foot terrice about a quarter of a mile north of Vaingana (fig. 2). At this locality, the limestone lies close to the underlying volcanic rock and is tuffaceous and partly weath ered; almost every where else on Eua the limestone is pure, hard, and crystalline.

In 1943, Harold T. Stearns, then of the U.S. Geological Survey, also served as a consultant to the Armed Forces at Pacific bases and made a brief visit to Eua. He collected a sample that contained half a dozen fossil brachiopods from the 400-foot terrace on the eastern side of the island. Stearns recorded the locality as: "Tele-a-hiva at elevation of 400 feet about $\frac{1}{2}$ mile north of army lookout tower, at the second stream north of Vaigana [sic]." "The brachiopods were examined by G. A. Cooper of the U.S. National Museum. Some years later when I was studying other island fossils collected by Stearns, Cooper showed me the brachiopods and expressed a desire for additional specimens so that he could continue his study of their internal structures.

In 1966, I learned that Yoshio Kondo of the Berrice P. Bishop Museum in Honolulu intended to visit Eua in connection with his studies of living Pacific island land snails (under National Science Foundation grant GB-3974). I sent Stearns' locality data and mar'zed copy of Hoffmeister's Eua map to Kondo, and I informed Stearns of the plan to collect additional material.

Late in August 1967, Kondo reached Eua and, aided by a Tongan guide, Tomiki, and an interpreter, Mosese Vea, spent 2 days searching for the fossil locality. The lookout tower mentioned by Stearns no longer exists and Kondo found that Tele-a-hiva translates to "Nine Gulches." Traveling northward from "Vaigana" (Otu Vaingana) through heavy brush on exceedingly rugred karst topography for about 1,000 feet, he reached the first of the gulches. There he found a soft fossiliferous layer between two harder limestones and collected a 
40-pound sample of the material. This gulch locality is probably not the exact spot visited by Stearns. The two collections have minor differences in nature of preservation, but they obviously came from the same formation.
In 1969 Wilfred Bryan of the Carnegie Institution of Washington collected additional material from the locality sampled by Kondo. Bryan's material was taken from soft calcareous tuffs 2-3 feet in thickness that dipped $30^{\circ}-40^{\circ}$ E. These calcareous tuffs were

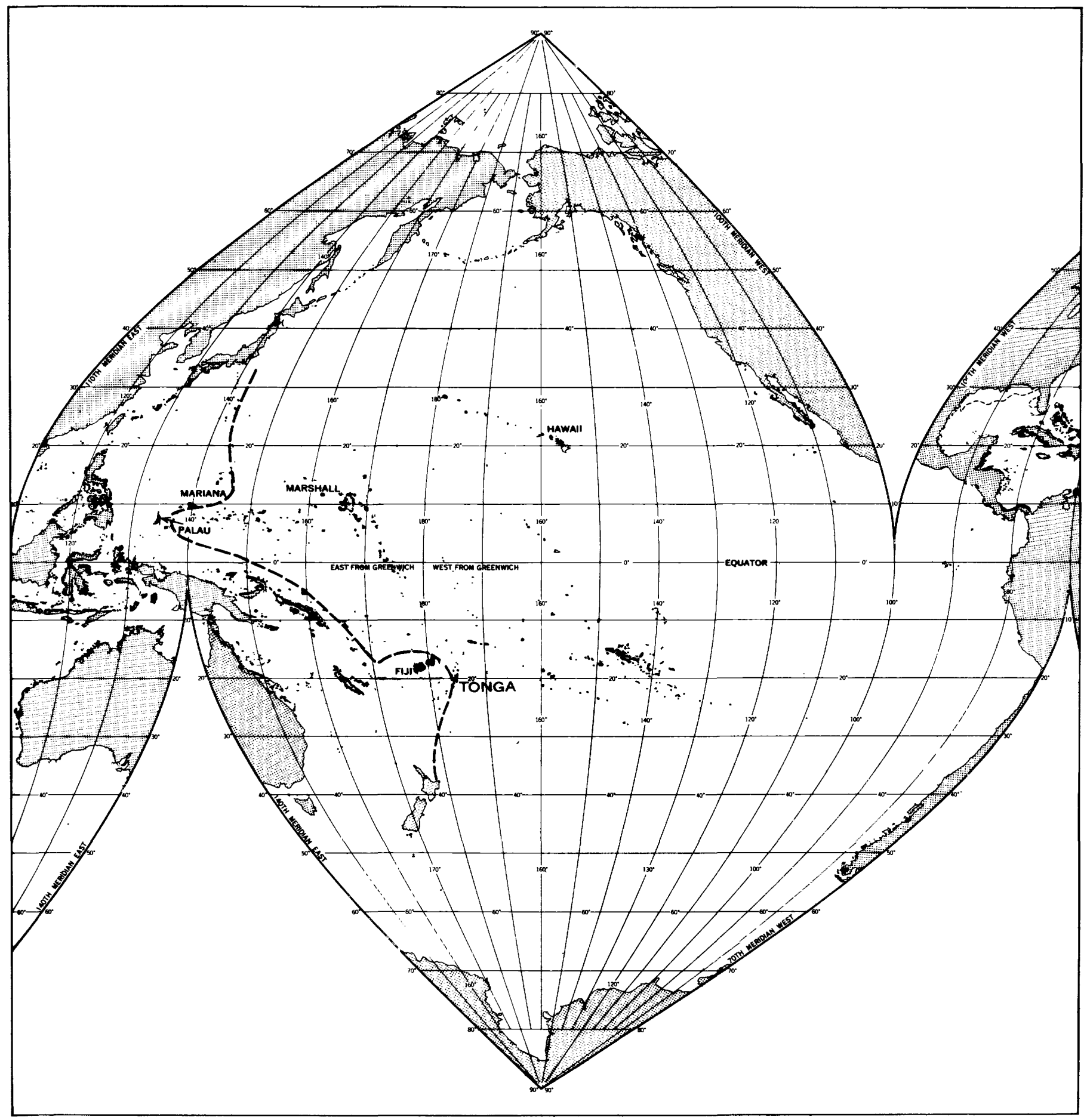

FIgURE 1.-Location of Tonga and other island groups in the southwest Pacific where upper Eocene limestone has been identified. Dashed line marks structural boundary of the Pacific Basin (andesite line). Islands shown include the surrounding reefs. 
directly underlain by several feet of harder fossiliferous material that, in turn, lay above agglomerate with truncated dikes. The horizon sampled was at an altitude of about 355 feet in a gully notched into the 400 -foot terrace.

The exact extent of the richly fossiliferous bed is not known. In 1926, when Hoffmeister made his

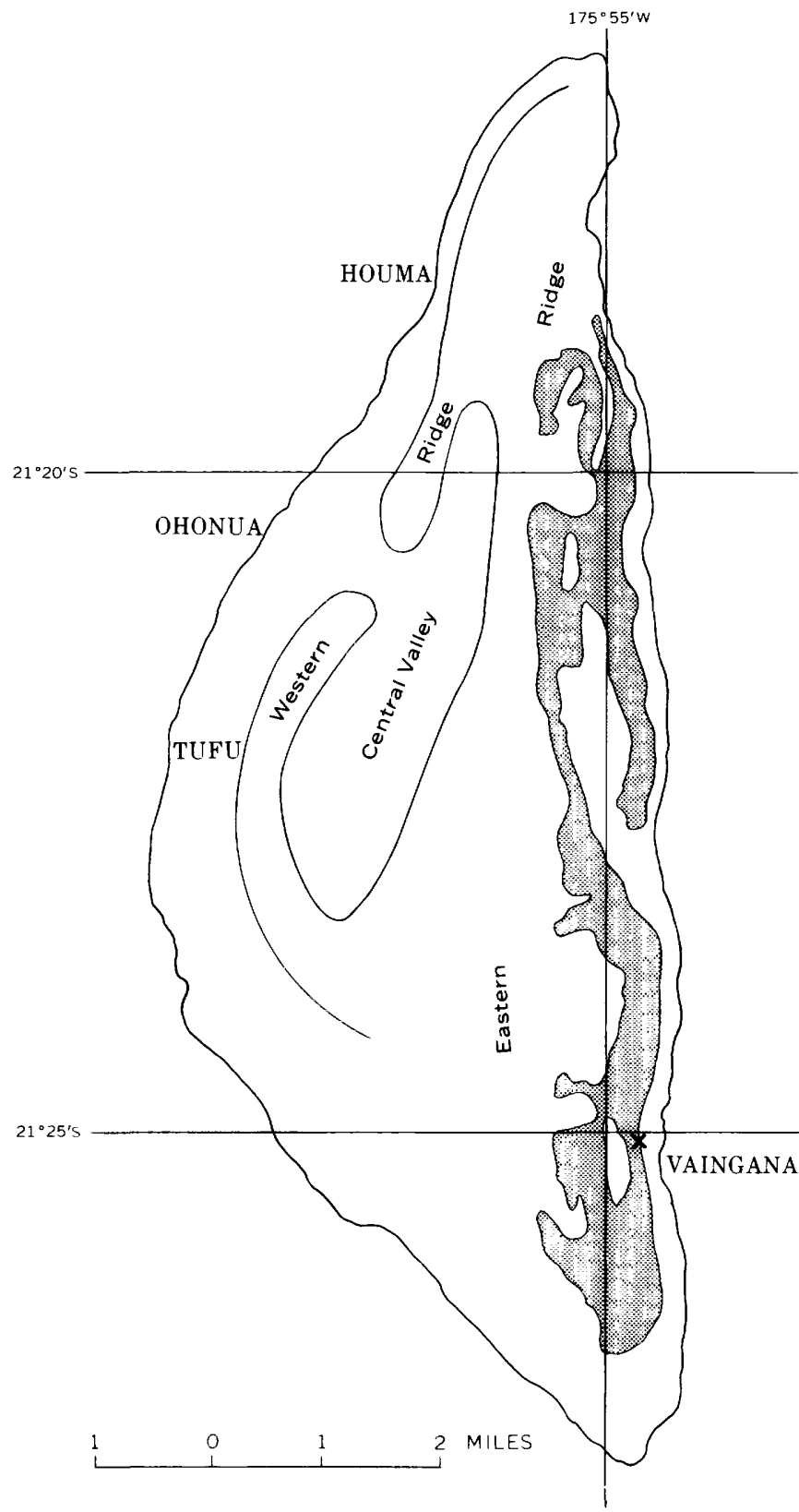

Figure 2.-Map of Eua, Tonga, showing the location of the recently discovered fossil outcrop $(x)$ and the main mass of Eocene limestone (patterned area) on the east side of the island, as mapped by Hoffmeister (1932). map of the terraces, he did not come upon this facies, and in 1928 when I spent 2 weeks on Eua with Hoffmeister, reviewing his mapping, no exposures of this zone were seen although we visited Vaingana. Additional fieldwork in the area of the rugged "Nine Gulches" would be worthwhile.

William Melson of the Smithsonian Institution examined hand specimens and thin sections of the tuffaceous limestone and noted that the volcanic constituents are highly altered, making it difficult to determine their original nature. The rock is composed of 50 percent or more of volcanoclastic debris, much of which has been replaced by calcite. The predominant volcanic fragments are of porphyritic pumiceous glassy material; most of the phenocrysts are plagioclase, now largely replaced by calcite. The original groundmass of pumiceous glass is row devitrified and dark brown. Fragments of tuff are rare. There appears to be a large and varied assemblage of secondary minerals. The volcanic fragments are mainly porphyritic andesitic rocks, or possibly plagioclase-bearing dacites. The presence of abındant fossils suggests that the volcanic material has been reworked.

The soft tuffaceous limestones collected on Fua were treated with a wetting agent and penetrant in the laboratory. The material broke down easily, revealing a variety of fossil remains: Foraminifera, discoasters, corals, hydrozoans, brachiopods, bryozoans, annelids, crinoids, echinoids, ostracodes, barnacles, decapod crustaceans, mollusks, shark teeth, otoliths, and spores and other plant microfossils.

W. Storrs Cole has described the larger Foraminifera; these fossils suggest to him a depth of deposition of about 200 feet, but other groups-notably the smaller Foraminifera, the corals, brachiopods, bryozoans, mollusks, ostracodes, and barnacles-point to a considerably greater depth of deposition.

Material representing a total of 17 organic groups was distributed to paleontologists for study and report. Seven of these collections were small or were made up of incomplete specimens leading only to summary reports, but the others, except for the larger Foraminifera, contained much new material. The brachiopod, bryozoan, ostracode, barnacle, $\varepsilon$ nd mollusk collections contained the first identifiable Eocene species from the islands of the open Pacific, an area extending 4,000 miles from Palau to Tonga.

HARRY S. LADD 



\section{CONTENTS}

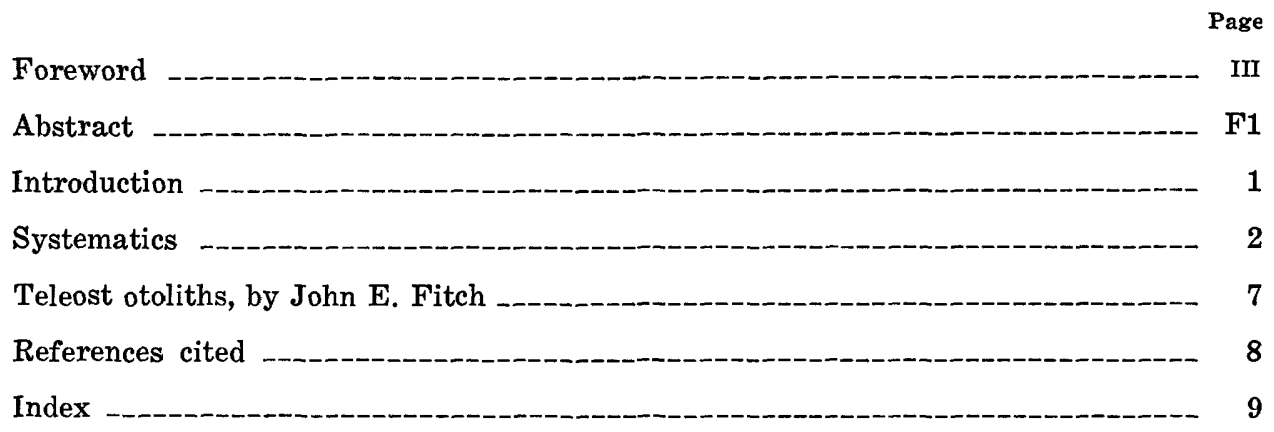

\section{ILLUSTRATIONS}

[Plate follows index]

Plate 1. Eocene brachiopods from Eua, Tonga.

Page

Figure 1. Map showing the location of Tonga and other island groups in the southwest Pacific where upper Eocene limestone has been identified

2. Map of Eua, Tonga, showing the location of recently discovered fossil outcrop and the main mass of Eocene limestone 
LATE EOCENE FOSSILS FROM EUA, TONGA

\section{EOCENE BRACHIOPODS FROM EUA, TONGA}

\section{BY G. ARTHUR COOPER ${ }^{1}$}

\section{ABSTRACT}

Six genera of brachiopods are recognized in Eocene strata from Eua in the Tonga Group. Three of the genera are uncertainly identified because of difficulties in obtaining interior details from the few specimens available. One genus, Aenigmathyris, proves to be new. All the genera, except the new one, have living descendants in the Pacific. Evidence as to the environment in which these brachiopods lived is inconclusive. Probably each had its own niche and they were swept together as a death assemblage.

\section{INTRODUCTION}

Any Eocene brachiopods are important, especially when they come from the Pacific from which few of them are known.

The details concerning the collecting of the specimens here described and a map of Eua showing the position of the locality are given in the "Foreword" (figs. 1, 2). Dating of the fossiliferous bed as late Eocene (Tertiary $b$ ) was accomplished by identification of Foraminifera (Todd, 1970; Cole, 1970).

The importance of the brachiopods from Eua cannot be overemphasized because they indicate the presence of stocks hitherto thought to be largely restricted to areas outside the Pacific. Although Thecidellina is known in the Miocene of New Zealand (Thomson, 1927, p. 141), it has hitherto not been reported from Eocene rocks in the Pacific realm. The same is true of Argyrotheca which is very rare in the Pacific today and, except for a species found in the Gulf of California, Mexico (Hertlein and Grant, 1944 , p. 105), is represented only by minute specimens similar to those described from Eua.

The two terebratulinids suggest a Cretaceous rather than an Eocene age as indicated in the systematic discussion. A variety of small to minute terebratulinids appears in the Upper Cretaceous of

${ }^{1}$ U.S. National Museum of Natural History, Smithsonian Institution, Washington D.C. 20560 .
Europe and some are known from the Upper Cretaceous of Cuba.

Great interest is now attached to interpretation of ecological conditions which might have obtained during the life of any fossils newly described. Modern brachiopods are often deceptive in this respect because some species have an exceptionally wide tolerance of depth and temperature. Terebratulina septentrionalis (Couthuoy), for example, is common in shallow Atlantic waters ranging from 5 to 100 fathoms, but this species has also been taken from 1,976 fathoms (Dall, 1920, p. 297-299). Another species, T. unguiculata (Carpenter) from Pacific waters, also has a fairly great depth range of 15 to 576 fathoms. Some species appear to be restricted to great deeps, such as Abyssothyris wyvillei (Davidson) and Neorhynchia streboli (Dall). Both species of Chlidonophora, which resemble the terebratulinid sp. indet. described below, are also confined to great deeps. Others, such as all species of Lingula and Glottidia, are confined to tidal waters or depths of a few (0-23) fathons. Actually, so little is known of modern brachiopots and their ecological tolerances that generalizations concerning them are unwise, and deductions concerning the kinds of fossils referred to modern genera are difficult to make. Generally, sound deductions must be based on criteria other than generic identity and comparison with modern species.

Another factor makes ecological deductions bas ad on the assemblage from Eua quite hazardous. T'e brachiopods occur together in a death assemblage which may have brought together specimens frcm several varying ecological niches. For example the numerous specimens of Dallithyris? are all jumbled together as single valves, many being broken and all being badly worn. Because no dorsal valve pro- 
serves the cardinalia or even the hinge plates, certain identification of the genus is prevented. These shells, obviously not in their original environment, were probably swept into their present state by strong currents. The small specimens, such as Argyrotheca, have both valves intact, but their small size would prevent them from being torn apart by vigorous currents. Small Argyrotheca are known from Bikini (Cooper, 1954) where they come from 50 fathoms and are associated with Thecidellina, which is usually found in fairly shallow water (less than 100 fathoms). All species of modern Dyscolia, the closest genus to Aenigmathyris, are deepwater dwellers (500 to 1,051 fathoms). Thus we have a hodge-podge of conflicting data based on brachiopods so that sound unequivocal decisions cannot be made.

Cole $(1970$, p. B3) concluded from an analysis of the Foraminifera that his fossils occupied warm, shallow waters "about 200 feet in depth." Ladd $(1970$, p. C2) concluded that although it is "difficult to evaluate the molluscan evidence, ... . it seems probable that the limestone represents offreef deposition at a depth of about 100 fathoms." Todd (1970, p. A1) concluded that the "great predominance of planktonic specimens in the Tonga sample, as much as 20 to 1, implies deposition at probably not less than 200 meters and in an area fairly distant from land." P. M. Kier (in Todd, 1970, p. A18) stated that the "echinoderm fragments indicate that the echinoderms lived in water deeper than 80 meters." These divergent views based on different animal groups indicate the present youthfulness of paleoecology, yet each of these authors might be right. Conceivably, the Eua deposit is a result of slide, or shifting debris on a slope front, that has come to rest in deeper water whose bottom is replete with planktonic Foraminifera. Such a death assemblage could include echinoderms, brachiopods, and other invertebrates from many separate niches.

\section{SYSTEMATICS}

The systematics of the specimens described herein are not entirely satisfactory because of scarcity of material and because of difficulty of preparation of interior details. No trouble was experienced in developing the loop of Aenigmathyris but the two terebratulinids defied all effort at development of their cardinalia. The family identity is largely based on exterior details, especially those of the hinge region, which are very distinctive in the Cancellothyridae.

Aenigmathyris Cooper, n. gen.

About medium size, biconvex, the ventral valve having the greater convexity; subpentagonal to ovate in outline; anterior commissure rectimarginate but with a tendency toward sulcation; beak short, truncated by a fairly large, strongly labiate, submesothyridid foramen; symphytium solid, visible. Surface marked by strong concentric lines of growth, crossed by very fine elevated radial lines especially on the flanks. Strongly punctate.

Ventral valve interior with stout testh but no dental plates; pedicle collar narrow, elevated. Other details not known.

Dorsal valve with short but wide cardinal process, strong thick socket ridges and steep, flattened inner hinge plates. Descending lamellae and crural processes combined and attached directly to the hinge plate; loop narrowly compressed, loop length equal to about one-third the valve length; anterior narrowly rounded; transverse ribbon broad and narrowly folded medially; no anterolateral extensions. Other details not known.

Type species.-Aenigmathyris stearrsi Cooper, n. sp.

Diagnosis.-Ovate shells with dyscoliiform loop.

Comparisons.- The narrow and elongated form of the loop with its narrowly rounded anter:or and lack of anterolateral extensions separates this genus from several of its homeomorphs such as Liothyrella, Gryphus, Dallithyris, and Abyssothyris. Its nearest affinities seem to be with Dyscolia but a number of significant differences exist, not only in the interior but also in the exterior. The beak region of Aenigmathyris is very much like Dyscolia with a fairly large foramen truncating the beak which is strongly labiate. Dyscolia has a very characteristic crnament of interrupted, wavy radial lines. The shell of Aenigmathyris, especially on its flanks, has very fine, elevated radial lines but they are direct and not wavy and interrupted. Dyscolia commonly is thickened anteriorly, especially in old shells, and this feature appears in some specimens of Aenigmathyris. Thus the exterior of Aenigmathyris is similar to that of Dyscolia but differs in the character of the microornament.

The cardinalia of Dyscolia resemble those of Aenigmathyris but important differences are apparent. The socket ridges and hinge plates of the two genera are very close and the cardinal processes are essentially the same, but the loop of Aenigmathyris is laterally compressed whereas that of Dyscolia is usually broadly rounded and fairly thin. A feature of the loop shared by the two genera is the combination of the descending branches with the crural processes so that the latter, which are not very 
pointed in either genus, appear to come directly from the hinge plate. The part of the Dyscolia loop anterior to the crural processes is wide and rounded but that of Aenigmathyris is narrow and the ribbon forming the loop is broad. The median part of the loop of Dyscolia is generally not strongly folded but that of Aenigmathyris has a strong, narrow, and angular fold. Although the two loops are very different in shape, that of Aenigmathyris is clearly dyscoliiform and the new genus is placed in the Dyscoliidae Fischer and Oehlert 1891.

At present four other genera are placed in the family Dyscoliidae: Dyscolia Fischer and Oehlert, Moraviatura Sahni, Trigonithyris Muir-Wood (with a query), and Waisiuthyrina Beets. All have a fossil record but only Dyscolia is living today in the Atlantic and Indian Oceans. Trigonithyris, doubtfully placed in the family, is from the Jurassic. Moraviatura is from the Cretaceous and Waisiuthyrina is from the upper Oligocene. Dyscolia is represented by a species in the Pliocene of Sicily but Liothyris gravida (Suess) from Ototaran beds at Momoe-aToa, Chatham Islands, as represented by specimens in the national collection, is definitely a Dyscolia with all of the characteristic wavy ornament. This places the genus in the Miocene and in the Pacific where hitherto it has not been known. Aenigmathyris in the Eocene may thus be an early relative of Dyscolia and was quite at home in the Pacific where Dyscolia is now not known to live.

\section{Aenigmathyris stearnsi Cooper, $\mathbf{n}$. sp.}

Plate 1, figures 25-48

Approximately an inch $(25 \mathrm{~mm})$ in length, oval to subpentagonal in outline; longer than wide with the maximum width at about midvalve; sides strongly rounded; anterior margin broadly rounded to subtruncate. Apical angle ranging between $80^{\circ}$ and $90^{\circ}$. Anterior margin rectimarginate to slightly sulcate. Beak erect to slightly incurved. Surface with numerous strong lines of growth and fine elevated radial lines concentrated on the flanks and anterior, stronger on the dorsal valve and poorly preserved or absent on median and umbonal parts of both valves. Punctae crowded.

Ventral valve evenly and moderately convex in lateral profile with the maximum convexity in the umbonal region; anterior profile broadly domed with short but steep slopes; beak region tapering; median region swollen; anterior slope short and rather steep.

Dorsal valve gently but unevenly convex in lateral. profile, the umbonal region the most convex, the median region somewhat flattened, and the anterior region moderately sloped; anterior profile broadly and very gently convex; beak inserted under symphytium; umbonal region slightly inflated; lateral and anterior slopes gentle.

Ventral valve interior poorly known but witr. a short elevated pedicle collar marginal to the inside of the foramen; muscles deeply inserted.

Dorsal valve interior with narrowly rounded and laterally compressed loop—socket ridges thick; inner hinge plates reduced; crural processes blunt forming a part of the descending branch of the loop; anterior part of loop with broad transverse band having a narrow, angular median fold. Other details of the interior not known.

\begin{tabular}{|c|c|c|c|c|c|}
\hline NM No. & Length & $\begin{array}{l}\text { Dorsal } \\
\text { valve } \\
\text { length }\end{array}$ & $\underset{\text { width }}{\text { Maximum }}$ & Thickness & $\underset{\text { angle }}{\text { Apical }}$ \\
\hline ---------- & 18.3 & 16.2 & 15.4 & 11.4 & $8 ?^{\circ}$ \\
\hline 49415 & 26.8 & 24.0 & 23.4 & 14.6 & $87^{\circ}$ \\
\hline $50447 \mathrm{a}$ & 22.3 & 19.5 & 20.0 & 12.3 & $8 ?^{\circ}$ \\
\hline $50447 \mathrm{~b}$ & 22.1 & 19.2 & 20.2 & 14.1 & $84^{\circ}$ \\
\hline
\end{tabular}

Diagnosis.-Subpentagonal Aenigmathyris with flanks and anterior marked by fine radii and $w^{\text {th }}$ stout laterally compressed loop.

Types.-Holotype: USNM 550447a. Figured paratypes: USNM549414a, b; 549415; 550447b; $549414 d$, e.

Discussion.-This genus and species is based on seven complete specimens in varying stages of praservation and two dorsal valves that were prepared to show the loop. One of the dorsals preserved part of the pedicle valve which was also cleaned and revealed the short pedicle collar. Only the holotype is an undamaged specimen. All the others have the valves displaced to a varying degree and one specimen has a fractured dorsal valve. The smallest specimen measures only $13.5 \mathrm{~mm}$ but is badly crushed. Although younger than all the others, it seems to be an adult.

It is hazardous to postulate the conditions unc'or which these specimens lived. The matrix filling them and in which they occur is a nearly white marl w:th small brown pellets. Whether they lived where they were entombed is an unanswered question. The foramen suggests a strong, stout, probably short pedicle which attached the bearer to its fellows and other shells.

The species is named for Dr. Harold T. Stearns who discovered the locality and collected the first specimens. 
Dallithyris? sp.

Plate 1, figures 23 and 24

About medium size for the genus, elongate trigonal in outline with straight sides and broadly rounded anterior margin; greatest width in the anterior third; anterior commissure rectimarginate to faintly uniplicate. Beak narrow, truncated by a small narrowly labiate foramen which is permesothyridid. Surface appearing smooth but marked by concentric lines of growth and a micro-ornament of very fine, crowded radial lines visible only in oblique light and seen chiefly on the flanks.

Pedicle valve moderately convex in lateral profile with the strongest convexity in the umbonal region and the anterior flattened; anterior profile narrowly domed and with long steep slopes; umbonal and median regions narrowly swollen; anterior slope long, moderately steep. Ventral muscle field elongate, anteriorly truncated.

Dorsal valve shallower than the ventral valve, moderately convex in lateral profile but broadly and moderately domed in anterior profile. Median region swollen.

\section{Measurements in millimeters.-}

\begin{tabular}{|c|c|c|c|c|c|c|}
\hline USNM No. & & Length & $\begin{array}{l}\text { Dorsal } \\
\text { valve } \\
\text { length }\end{array}$ & $\underset{\text { width }}{\text { Maximum }}$ & Thickness & $\begin{array}{l}\text { Apical } \\
\text { angle }\end{array}$ \\
\hline $550446 \mathrm{a}$ & - - - - - & 20.2 & $?$ & 15.8 & 10.2 & $56^{\circ}$ \\
\hline $550446 \mathrm{~b}$ & ---------- & 19.5 & ? & 16.7 & 7.6 & $60^{\circ}$ \\
\hline $550446 \mathrm{c}$ & - & 18.7 & $?$ & 15.5 & 9.6 & $70^{\circ}$ \\
\hline
\end{tabular}

Diagnosis.-Dallithyris strongly tapered posteriorly and with triangular outline.

Figured specimens.-USNM 550446a, b.

Discussion.-The above description is based on a few good valves out of a large number of fragmentary specimens. The collection consists. of numerous specimens but all the dorsal valves are badly broken and only a half dozen of the ventral valves are in good condition. The specimens are nearly all discolored, the discoloration ranging from rich chocolate to black. The matrix is a cream-colored marl with brown pellets. Not a single specimen was collected with both valves in place; consequently the loop is unknown. Furthermore, the few dorsal valves that show any of their cardinalia have only damaged hinge plates with no trace of a loop. The hinge plates are shallow and concave and no trace of a cardinal process was seen.

The jumbled character of the specimens in matrix, the separation of the dorsal from the ventral valves, and the presence of very few dorsal valves suggest reworked, dead specimens piled together from some other environment than that in which they were ultimately entombed.

The exterior of this species suggests the form of Dallina or Gryphus sphenoidea (Philippi) of the Mediterranean Tertiary and Dallithyris murrayi Muir-Wood of the Indian Ocean. The anterior folding is not in accordance with Dallina but the unequally convex and shallow dorsal valves suggest the other two species.

\section{Terebratulina? sp. \\ Plate 1, figures 20-22}

Very small, trigonal in outline with the greatest width anterior to the middle; sides and anterior well rounded; hinge narrower than midvalve width and with small ears; delthyrium large and open; beak narrowly rounded; valves subequally convex. Surface marked by closely crowded, strongly beaded costellae. Interior not known.

\begin{tabular}{lcccc}
\multicolumn{5}{c}{ Measurements in millimeters.- } \\
\multicolumn{5}{c}{$\begin{array}{c}\text { Dorsal } \\
\text { valve }\end{array}$} \\
USNM No. & Length & length & W:dth & Thickness \\
$550443 \mathrm{a}-1.9$ & 2.2 & 2.3 & 1.2 \\
$550443 \mathrm{~b}--$ & 2.9 & 1.8 & 1.9 & 0.9
\end{tabular}

Discussion.-These small specimens possess the characters of an immature Terebratulina: open foramen with no deltidial plates and stror oly beaded costae. These features are also the external characteristics of Rugia Steinich (1963) from Upper Cretaceous sedimentary rocks in Denmark. The collection contains only four specimens, one of which is a fragmentary ventral valve with interior details. But this does not help with generic definition. Even if the interior of the dorsal valve were lnown it is doubtful whether it would be possible to distinguish Rugia from immature Terebratulina in which the crural processes had not yet fused. Consequently it seems best to refer the Eua specimens tc Terebratulina which has a long geological history and occurs in all parts of the world. These little specimens do not tell an ecological story with our present, knowledge of the genus. Terebratulina is usually a shallowwater genus. The deepest record given by Dall (1920, p. 299) who lists most of the Holocene species, is for T. septentrionalis (Couthouy) from 1,976 fathoms off Martha's Vineyard, Mass. Most of the records are above 500 fathoms and many are les $^{\sim}$ than 100 fathoms.

These little shells are almost identical to small but fairly wide-hinged terebratulinids in the Eocene of Cuba which also are suggestive of Rugia. I have been 
unable to expose the loops of any of these tiny brachiopods.

\section{Terebratulinid, gen. and sp. indet.}

Plate 1, figures 14-19

Minute, pentagonal in outline with the sides nearly straight and the anterior margin broadly rounded; posterolateral margins converging to form an angle of about $100^{\circ}$. Valves unequal in depth, the ventral valve being much deeper than the dorsal one; hinge straight, wide, nearly equal to the maximum shell width which is near midvalve; anterior commissure rectimarginate. Beak incurved, foramen large, triangular. Surface marked by costellae, strongest in the anteromedian region but fading out on the posterolateral extremities. Costellae about six on a side with a median one the strongest of all.

Ventral valve strongly convex in lateral profile; strongly domed and with long steeply sloping sides in anterior profile; umbonal region narrowly swollen, the swelling continuing medially to the anterior margin. Dorsal valve flatly convex in lateral profile but broadly and very gently convex in anterior profile; fold marked by the single costa stronger than the others which opposes a narrow groove on the ventral valve.

Interior not known except for an apical plate in the pedicle valve against which the pedicle rested.

\begin{tabular}{lcclll}
\multicolumn{2}{c}{ Measurements in millimeters.- } \\
\multicolumn{5}{c}{$\begin{array}{c}\text { Dorsal } \\
\text { valve }\end{array}$} \\
USNM No. & Length & length & Width & Thickness \\
$550445 \mathrm{a}$ & 1.55 & 1.2 & 1.4 & 0.75 \\
$550445 \mathrm{~b}$ & - & 1.7 & 1.4 & 1.55 & 0.9
\end{tabular}

Figured specimens.-USNM 550445a, b.

Discussion.-These little specimens have the external characters of several genera and, in absence of the interior details, it is impossible to say to which one they belong. They suggest Eucalathis but that genus is usually more triangular and has a narrower hinge. Chlidonophora has a wide hinge like the Eua specimens but has a less incurved beak, smaller foramen, and a more finely costellate shell. Furthermore, the dorsal valve is somewhat keeled medially and has a swollen umbonal region. Orthothyris of the Cuban Cretaceous is similarly shaped and wide hinged, but it is costate rather than costellate. Only by discovery of the loop will it be possible to assign this interesting minute brachiopod to its proper genus. Several specimens were destroyed in an effort to determine the loop. The collection is too limited in numbers to sacrifice more specimens.
Argyrotheca anomala Cooper, n. sp.

Plate 1, figures 7-13

Minute, longer than wide and having a subtri६nnal or subpentagonal outline; widest anteriorly; sides slightly rounded to straight; anterior margin $\mathrm{g}$ ?ntly rounded to moderately indented medially. Lateral profile lenticular; valves uneven in depth, the pedicle valve having the greater depth. Beak elongated; foramen large, triangular, open, margined by rudimentary deltidial plates. Surface smooth.

Ventral valve gently convex in lateral profile, broadly and flatly domed in anterior profile; fanks slightly swollen but median and anterior rexions flattened to form a gentle sulcus of varying derth in different specimens.

Dorsal valve in lateral profile varying from very gently convex to slightly concave; convexity strongest at the umbo; interior profile forming a lroad dome, gently concave medially but with convex sides; umbonal region swollen, the swelling continuing to midvalve where a shallow but broad sulcus is formed to indent the anterior margin. Flanks moderately convex. Lateral slopes fairly steep.

Ventral interior with a low median ridge, all other details obscure. Dorsal valve interior with strong, elevated socket ridges; median septum originating slightly posterior to midvalve, forming a crest at about two-thirds of the valve length and with $\varepsilon$. concave anterior slope which is crudely serrate. No trace of a loop.

\begin{tabular}{|c|c|c|c|c|c|}
\hline NM No. & & Length & $\begin{array}{l}\text { Dorsal } \\
\text { valve } \\
\text { length }\end{array}$ & $\underset{\text { width }}{\text { Maximum }}$ & Thickness \\
\hline $0442 \mathrm{a}$ & --n-- - - - - - - - & -2.2 & 1.8 & 2.0 & 0.8 \\
\hline $50442 f$ & - & -2.0 & 1.5 & 1.8 & 1.0 \\
\hline
\end{tabular}

Diagnosis.-Elongate, smooth Argyrotheca.

Types.-Holotype: USNM 550442a. Figured paratypes: USNM 550442b-e. Unfigured paratype: USNM 550442f.

Comparison and discussion.-Argyrotheca is a very prolific genus with a range into the Cretaceous. Nearly all the known species of Argyrotheca aro plicated but a few such as $A$. akymatophora Stenzel and $A$. powersi Gardner are smooth or near'y so. I know of only one species, A. mayi (Blochmann), having the characters of the Eua species. Most specimens of Argyrotheca are wider than the are long or have length and width nearly equal, but none are terebratuliform as is $A$. anomala. The small size and nudity of $A$. anomala might suggest that the 
species is an immature form, but all of the many specimens are nearly of the same size; they do not show enlarged punctae as is common in all immature punctate terebratulids or terebratellids and the shells and septa are thick, not delicate as in immature specimens.

Argyrotheca is not well known in the Pacific but three species have been described: $A$. mayi (Blochmann) and $A$. australis (Blochmann) are from the southern hemisphere and $A$. lowe $i$ Hertlein and Grant is from the Gulf of California. A. lowe $i$ is a large, wide, plicated form and does not compare with $A$. anomala. $A$. australis is also a ribbed form and not comparable with the Eua species. A. mayi is an elongated and smooth species strongly suggestive of $A$. anomala. It is $2.5 \mathrm{~mm}$ long, $2 \mathrm{~mm}$ wide, and $1.0 \mathrm{~mm}$ thick. Its measurements are thus almost exactly like those from Eua but Blochmann's species is subrectangular longitudinally, its foramen much more strongly indented anteriorly than the Eua species. Although the exterior of the two species is similar, the interiors are entirely unalike. The septum of the dorsal valve of $A$. mayi is less well developed than that of $A$. anomala but that of the ventral valve is more strongly developed. It is remarkable that a species living today should be externally so like the Eocene species of Eua.

Cooper (1954) described a small Argyrotheca from the Holocene at Bikini but this is differently shaped than the Eua species and $A$. mayi. It is transversely rectangular in outline rather than elongate and has incipient costae.

The Eocene of Cuba and other Tertiary deposits in the Caribbean region are rich in species of Argyrotheca. This is true also of the Tertiary of the Gulf States of the United States. In the Caribbean region all described species are moderately large for the genus and are costate. They certainly represent a more advanced state of development than those of Eua. The few species known from the Cretaceous are also costate and more advanced than those of Eua. The Pacific, like the Indian Ocean, so far as present knowledge goes, is not prolific in this genus. The same may be said of the Pacific Tertiary as the only Argyrothecas reported are from New Zealand and Australia. None has been reported from Japan. The restriction of the genus at present to the tropical regions on either side of the equator, north to the Mediterranean and south to Australia, suggests warmer waters as a requirement for their well-being.

\author{
Thecidellina sp. \\ Plate 1, figures 1-6
}

Small, nearly circular in outline, but with the posterior margin made irregular by the cicatrix of attachment. Hinge width about half of the valve width. Ventral valve larger than the dorsal valve and forming a flattened triangle in lateral profile; attachment cicatrix fairly large, occupying on?-third to two-thirds of the valve length. Dorsal valve shallow and gently convex in lateral profile and with a short interarea. Maximum convexity at about midvalve.

Ventral valve interior with stout teetr; pseudodeltidium short, leaving a large gap for rereption of the cardinal process; hemispondylium not visible. Dorsal valve interior with long squarist cardinal process, hollow internally and with a small median septum; rim narrow and strongly pustuloso; median ridge slender not widening strongly anteriorly.

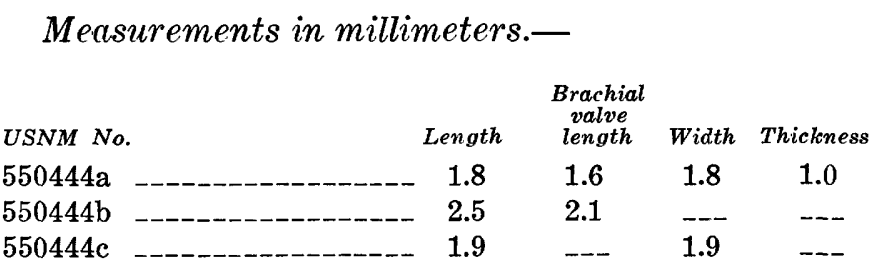

Diagnosis.-Very small, nearly circular Thecidellina with slender median ridge in dorsal valve which has a narrow pustulose marginal rim.

Comparison and discussion.-The proportions and interior development of the four specimens in the collection suggest that they are adults of a very small species. The interior of the dorsal valve has all the features of an adult in the well-develop $n$ median ridge and the strongly pustulose marginal rim. Compared with small specimens of $T$. congregata Cooper from Bikini Atoll, the Eua specimens are much rounder in dorsal aspect and are much more convex. No young of T. maxilla (Hedley) of comparable size to the Eua specimens are available for ccmparison.

This is the earliest representative of Thecidellina in the Pacific. It is known in the Miocene of New Zealand ( $T$. hedleyi Thomson, 1915, p. 463) and from sediments of the same age from drill holes in Bikini and Eniwetok. Thecidellina is known from the Eocene of the United States (T. cooperi Toulmin, 1940, p. 228) and from specimens not yet described. It is also known from undescribed specirens from the Eocene of Cuba. Thus the genus has an ancient lineage but its roots in the Cretaceous are still to be found. 
Thecidellina is fairly common in present seas around the West Indies and in the Pacific around Bikini, Fiji, and Guam. In the Indian Ocean it was found at Christmas Island. Throughout this vast range its deepest record is 150 fathoms from the Caribbean. The deepest record in the Pacific is from Bikini Atoll where it was taken from 133 fathoms although the specimens were ventral valves on coral and may not have lived at this depth.

\section{TELEOST OTOLITHS}

By John E. Fitch ${ }^{2}$

Fifty-two recrystallized otoliths and otolith fragments were available for study. These bore the collection number USGS 24745 and had been gleaned from material collected in 1969 by Wilfred Bryan of the Geophysical Laboratory of the Carnegie Institution of Washington. The locality of collection on Eua, Tonga, was the same as that sampled in 1967 by Yoshio Kondo of the Bernice P. Bishop Museum (Harry S. Ladd, written commun., 1970).

For determining family relationships, the most important single feature of any teleost sagitta is the sulcus (that is, an imprint or channeled groove on the inner face of the otolith), but details of the sulcus had been obliterated, presumably during recrystallization, on all but one of these 52 otoliths. In spite of this, sufficient characters were observable on 26 of the otoliths to determine that these represented 10 kinds of fish, but only six of these "species" could be placed in "families" with any feeling of certainty: two in flatfish, one in Macrouridae, and three in Myctophidae.

Flatfishes, of which there are six families, generally are associated with a marine environment and flat bottom topography. Various genera and species range from the shallow subtidal region into depths exceeding 1,080 fathoms. A few species are known from polar seas, but all families are represented in tropical waters where flatfishes have attained their greatest generic diversity. No fossil flatfishes are known from the Cretaceous, but several modern families were well established by middle Eocene. Weiler (1968), on the basis of otoliths, lists nine Eocene species in three families, and skeletal remains of the same age are known from several European localities. None of the flatfish otoliths from Eua could be assigned to a definite family but since the

2 Marine biologist, California State Fisheries Laboratory, Long Beach, California 90802 . sulcus of one did not appear to reach the otolith margin, it probably was from a bothid (Bothidae). In the family Cynoglossidae, the sulcus also fails to reach the otolith margin, but the angular outline of the Eua otolith precludes its placement with the tonguefishes. Although the other two flatfish otcliths represented a different species, they were impossible to identify except as flatfish.

Macrourids are the most characteristic and a.bundant of all benthic deep-sea fishes, being found in all seas and at all depths with the conspicuous exception of the Polar Basin (Grey, 1956). They generally inhabit muddy bottom areas at depths exceeding: 108 fathoms, but on rare occasions macrourids are captured in shallower water. The family enjoys an extremely rich fossil record with otoliths being found as early as Paleocene in British deposits (Weiler, 1968). The five macrourid otoliths from Eua were probably from a single species, but their exceedingly poor condition would not permit speculation as to generic affiliation.

Lanternfishes (Myctophidae) are typical mesopelagics which inhabit scattering layers throughout the world oceans. Most myctophids undertake diurnal migrations, moving upward at night, sometimes to the ocean's surface and returning to the depths during daylight hours. Most California species for which data are available have a center of diurnal distribution between 246 and 383 fathoms beneath the surface (Paxton, 1967). Temperature and light appear to be the most important ecologic determinants of vertical distribution, and there is no reason to suspect that conditions are different elsewhere in the world. Although solitary fish scales fourd in Cretaceous chalks of Alabama are thought to be from lanternfish, is no positive record of the family prior to the Eocene (Fitch, 1969). Myctophid remains, particularly otoliths, are extremely abundart in fossil deposits throughout the world (Weiler, 1968; Fitch, 1969, and unpub. data). The 13 myctophid otoliths from Eua represent three distinct species, with 11 being from a single species.

On the basis of knowledge of the preferred environments of the present-day relatives of these few faunal components, depth of deposition would al nost certainly have exceeded 182 fathoms. Bottom sediments dredged from depths of 76 fathoms ir the Indian Ocean contained an admixture of otcliths from shallow- and moderate-depth species, whereas otoliths in sediments from depths exceeding 383 
fathoms in the Gulf of California showed a greater correlation with the Eua otoliths. Otoliths of myctophids frequently are found in sediments desposited at much shallower depths, but in these instances they seldom contribute more than a very minor portion to the total otolith yield, and rarely is there more than one species of myctophid. With additional sampling recognizable otoliths of congrids, bregmacerotids, berycids, and brotulids might be discovered in the tuffaceous limestone on Eua, which would strengthen the hypothesis of deposition at relatively great depth.

My work with fossil otoliths has been made possible by research grants (GB-1244 and GB-6490) from the National Science Foundation under the sponsorship of the Los Angeles County Museum of Natural History Foundation.

\section{REFERENCES CITED}

Asano, Kiyoshi, 1939, Limestones of the South Sea Islands under the Japanese Mandate: Yabe Jubilee Pub., v. 1, p. 537-550.

Cole, W. S., 1950, Larger Foraminifera from the Palau Islands: U.S. Geol. Survey Prof. Paper 221-B, p. 21-31. - 1957a, Larger Foraminifera, in Part 3, Paleontology, of Geology of Saipan, Mariana Islands: U.S. Geol. Survey Prof. Paper 280-I, p. 321-360.

1957b, Larger Foraminifera from Eniwetok Atoll drill holes: U.S. Geol. Survey Prof. Paper 260-V, p. 743-784 [1959].

1960, Upper Eocene and Oligocene larger Foraminifera from Vitu Levu, Fiji: U.S. Geol. Survey Prof. Paper 374-A, 7 p. [1961].

_ 1970, Larger Foraminifera of late Eocene age from Eua, Tonga: U.S. Geol. Survey Prof. Paper 640-B, 17 p., 5 pls., 2 figs.

Cooper, G. A., 1954, Recent brachiopods, in Part 2, Oceanography (biologic), of Bikini and nearby atolls, Marshall Islands: U.S. Geol. Survey Prof. Paper 260-G, p. 315-318, pls. 80,81 .
Dall, W. H., 1920, Annotated list of recent Brachicpoda in the collection of the United States National Museum, with descriptions of thirty-three new forms: U.S. Natl. Mus. Proc., v. 57, p. 261-377.

Fitch, John E., 1969, Fossil lanternfish otoliths of California, with notes on fossil Myctophidae of North America: Los Angeles County Mus. Contrib. in Sci., no. 173, p. 1-20.

Grey, Marion, 1956, The distribution of fishes found below a depth of 2,000 meters: Fieldiana-Zoology, v. 36, no. 2, p. 73-337.

Guest, N. J., 1959, Geological mapping, Tonga: Fiji Geol. Survey Dept., Ann. Rept. for 1958, Council Paper 17, p. 3.

Hertlein, L. G., and Grant, U. S., IV, 1944, The Cenozoic Brachiopoda of western North America: California Univ. Pub. Math and Phys. Sci., v. 3, p. 1-236, 21 pls., 34 figs.

Hoffmeister, J. E., 1932, Geology of Eua, Tonga: Bernice P. Bishop Mus. Bull. 96, 93 p.

Ladd, H. S., 1970, Eocene mollusks from Eua, Tonga: U.S. Geol. Survey Prof. Paper 640-C, 12 p., 5 pls.

Paxton, J. R., 1967, A distributional analysis for the lanternfishes (Family Myctophidae) of the San Padro Basin, California: Copeia, 1967, no. 2, p. 422-440.

Steinich, Gerhard, 1963, Drei neue Brachiopodengattungen der Subfamilie Cancellothyrinae Thomson: Geolngie, Jahrg. 12, H. 6, p. 732-740, 8 figs.

Thomson, J. A., 1915, A new genus and species of the Thecidiinae: Geol. Mag., decade 6, v. 2, no. 10, p. 461-464.

- 1927, Brachiopod morphology and genera (Recent and Tertiary): New Zealand Board Sci. and Art Manual, no. 7, 338 p., 2 pls., 103 figs.

Todd, Ruth, 1970, Smaller Foraminifera of late Eocene age from Eua, Tonga: U.S. Geol. Survey Prof. Paper 640-A, 23 p., 8 pls., 4 figs.

Toulmin, L. D., 1940, Eocene brachiopods from the Salt Mountain limestone of Alabama: Jour. Paleontology, v. 14, no. 3, p. 227-233, pl. 28.

Weiler, Wilhelm, 1968, Otolithi Piscium (Neubearbeitung), Part 117 of Westphal, F., ed., Fossilium C-talogus. I. Animalia: The Hague, W. Junk N.V., 196 p. 


\section{INDEX}

[Italic numbers indicate major references and descriptions]

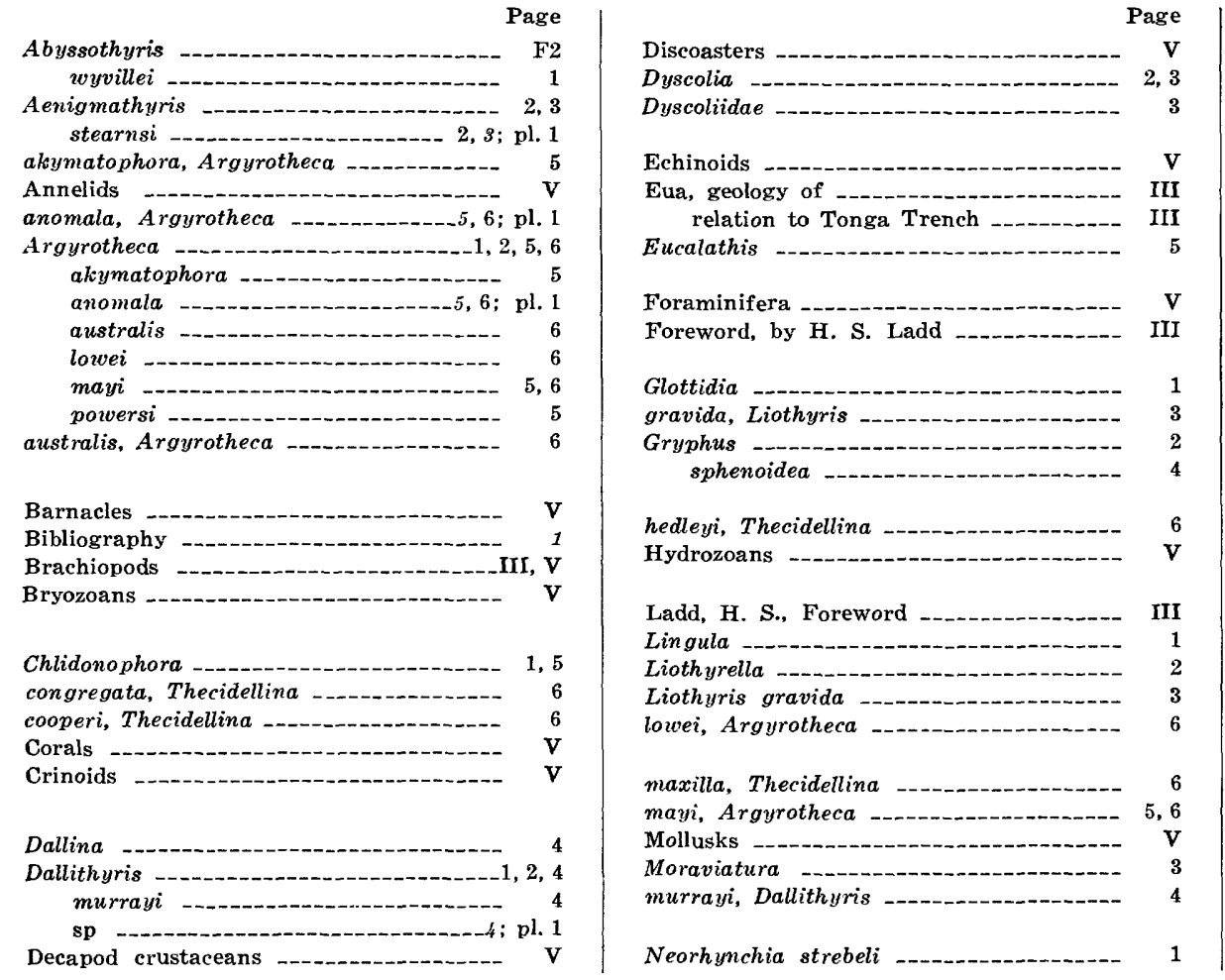

Page

Orthothyris -..--

Ostracodes -

Otoliths _............- V

Plant microfossils -

powersi, Argyrotheca -

Rugia -_.

septentrionalis, Terebratulina _..._._._._ 1,4

Shark teeth -...

sphenoidea, Gryphus ...._. 4

Stearns, H. T., quoted -_-_-_-_-_ III

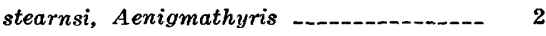

strebeli, Neorhynchia

Terebratulina --.-- 4

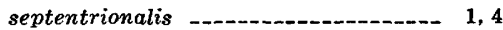

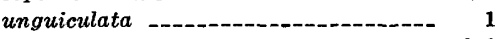

sp -

Terebratulinid _-_-_._-_-_-_-_ 5 ; pl. 1

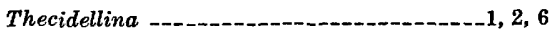

congregata --.-- 6

cooperi -...- 6

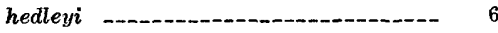

maxilla --1.-1- 6

sp -

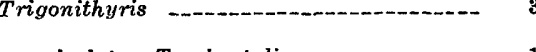

unguiculata, Terebratulina _-_-_- 1

Vaingana --1.-_- III

Waisiuthyrina -

wyvillei, Abyssothyris _._.............. 1 



\section{PLATE 1}

Contact photographs of the plate in this report are available, at cost, from

U.S. Geological Survey Library, Federal Center, Denver, Colorado 80225. 


\section{PLATE 1}

Figure 1-6. Thecidellina sp. (p. F6).

1-3. Ventral, side, and dorsal views of a complete specimen, $\times 10$, figured specimen USNM 550444a.

4,5. Exterior and interior of the dorsal valve, $\times 10$, showing the strong median ridge, figured specimen USNM $550444 \mathrm{~b}$.

6. Interior of the ventral valve showing teeth and flat deltidial region, $\times 10$, figured specimen USNM 550444c.

7-13. Argyrotheca anomala Cooper, n. sp. (p. F5).

7-9. Dorsal, ventral, and side views of a complete specimen, $\times 10$, holotype USNM 550442a.

10. Dorsal view of a young individual with strongly emarginate anterior, $\times 10$, paratype USNM 550442b.

11. Interior of the dorsal valve showing the strong median septum so characteristic of the genus, $\times 10$, paratype USNM $550442 \mathrm{c}$.

12. Interior of the ventral valve, $X 10$, showing the median ridge, paratype USNM 550442d.

13. Dorsal view of an adult showing open foramen, paratype USNM $550442 \mathrm{e}$.

14-19. Terebratulinid, gen. and sp. indet. (p. F5).

14-16. Anterior, side, and dorsal views, $\times 10$, showing ornament, figured specimen USNM 550445a.

17-19. Side, anterior, and dorsal views, $\times 10$, of another, larger specimen, figured specimen USNM 550445b.

20-22. Terebratulina? sp. (p. F4).

Side, ventral, and dorsal views of a strongly beaded specimen, $\times 10$, figured specimen USNM 550443a.

23, 24. Dallithyris? sp. (p. F4).

Dorsal and ventral valves, $\times 1$, showing trigonal form of ventral valve, figured specimens USNM 550446a, b.

25-48. Aenigmathyris stearnsi Cooper, n. sp. (p. F3).

25-29. Dorsal, posterior, ventral, anterior, and side views of a young individual, $\times 1$, paratype USNM 549414b.

30-33. Posterior, side, dorsal, and anterior views of an undistorted specimen, $\times 1$, holotype USNM 550447a.

34-37. Ventral, dorsal, side, and anterior views of a larger but damaged specimen, $X 1$, paratype USNM 549414 a.

38-41. Anterior, ventral, side, and dorsal views of another large but imperfect paratype, $\times 1$, USNM 549415 .

42-45. Anterior, side, dorsal, and posterior views of another paratype, $\times 1$, USNM 550447b.

46. Dorsal view of preceding specimen, $\times 2$, showing traces of radial ornament.

47,48 . Interior of two dorsal valves, $\times 3$, showing the loop with rounded anterolateral extremities, paratypes USNM 549414e, d. 


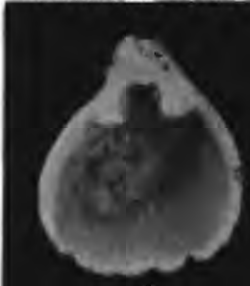

6
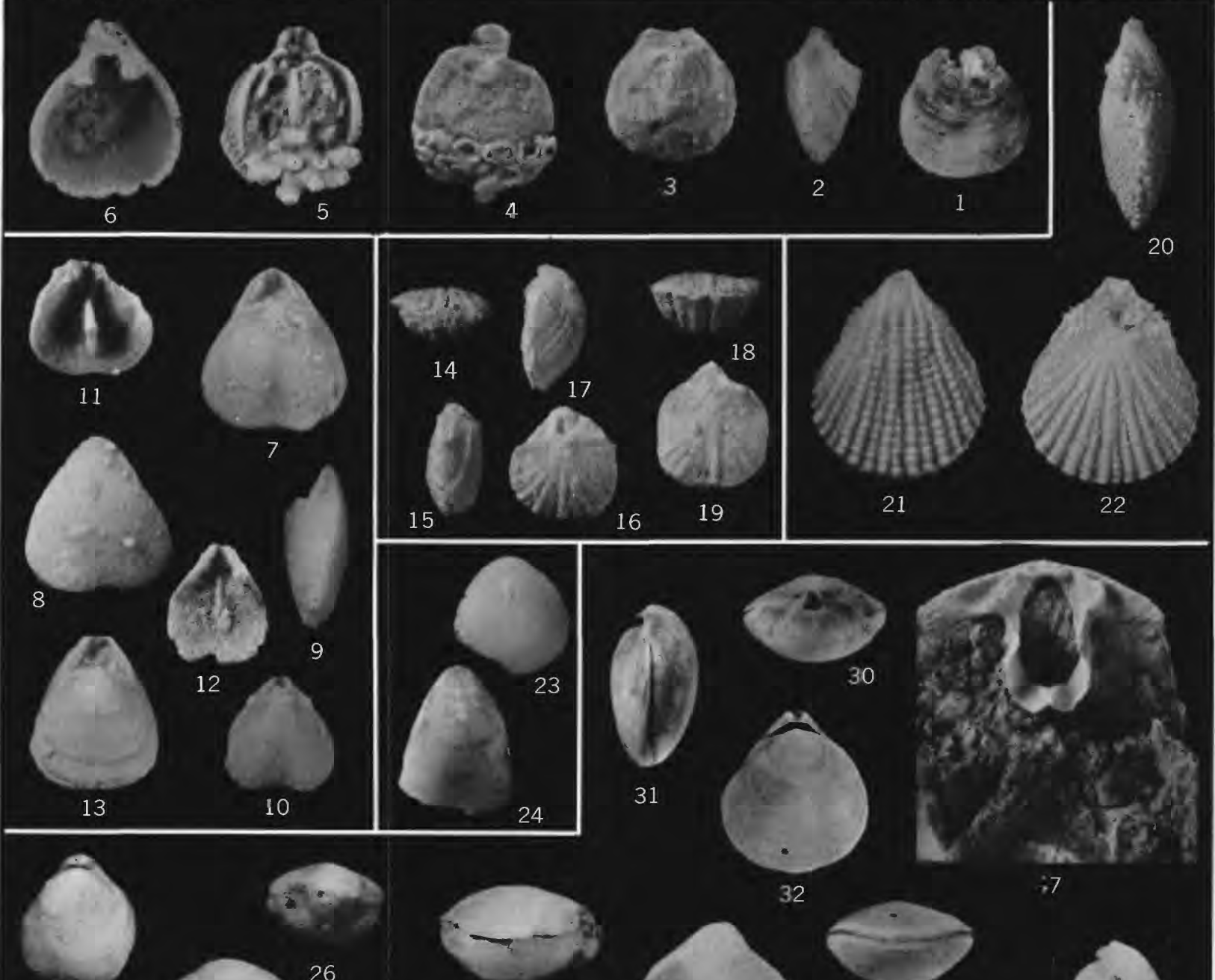

25

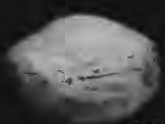

$x^{2} \cdot 1$

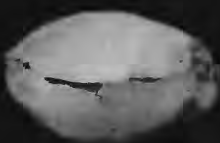

26
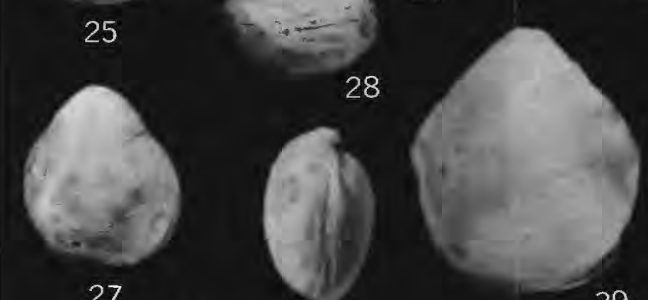

39
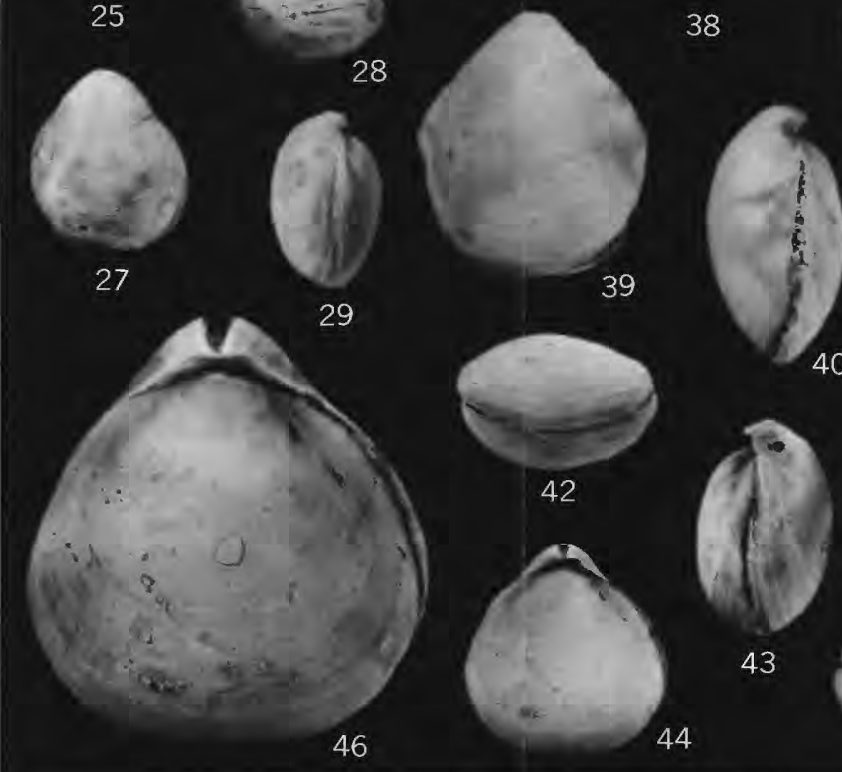

43

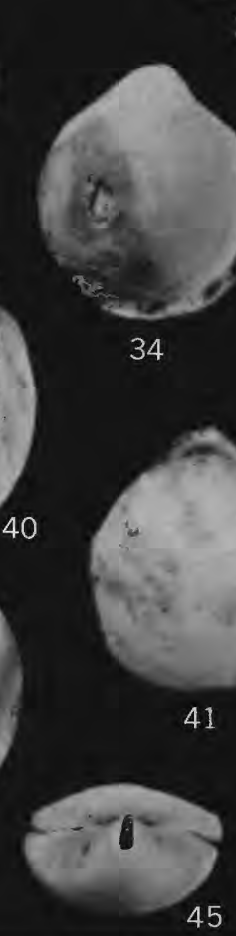

77

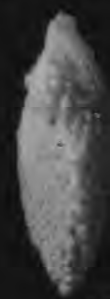

2

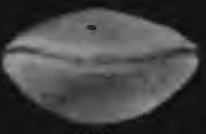

33

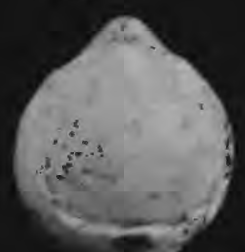

35

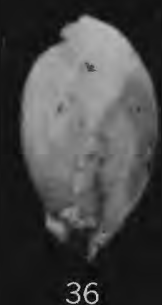

36

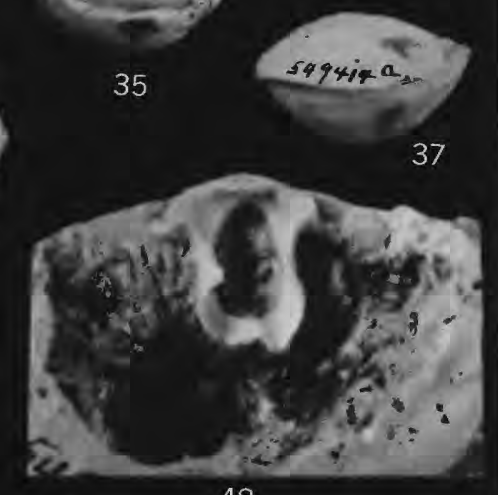

48

EOCENE BRACHIOPODS FROM EUA, TONGA 